\title{
The emerging small-scale cattle farming sector in Uzbekistan: Highly integrated with crop production but suffering from low productivity
}

M. SIEGMUND-SCHULTZE ${ }^{1 *}$, B. RISCHKOWSKY ${ }^{2}$, I. YULDASHEV ${ }^{3}$, B. ABDALNIYAZOV ${ }^{4}$, J.P.A. LAMERS ${ }^{5}$

\author{
${ }^{1}$ Berlin Institute of Technology (TUB), Germany \\ ${ }^{2}$ International Center for Agricultural Research in the Dry Areas (ICARDA), Syria \\ ${ }^{3}$ ZEF-UNESCO Khorezm Project, Uzbekistan \\ ${ }^{4}$ Urganch State University (UrSU), Uzbekistan \\ ${ }^{5}$ University of Bonn, Center for Development Research (ZEF), ZEF-UNESCO Project, \\ Uzbekistan
}

*Corresponding author. E-mail: m.siegmund-schultze@ @u-berlin.de (M. SiegmundSchultze)

\section{ABSTRACT - up to 200 words!}

Since independence in 1991, reforms in the agricultural sector of Uzbekistan have aimed at replacing large-scale governmental farms with medium-scale private farms. However, this sector still is regulated by the government, for example, through prescribing the number of cattle head per agricultural area and-or imposing mandatory cash crops-on private, irrigated mixed farms. Yet, Tthe present policy makers are insufficiently informed about the bottlenecks in the different livestock production units and base their policies mainly on general knowledge. This study analysed the two major livestock cattle farm types in the Khorezm province, 56 medium-scale farms (LS; on average 22 ha) and 80 household farms $(\mathrm{HH}$; on average 0.2 ha). In these irrigated mixed farms, cattle feeds were composed mainly of crop residues. While LS farms produced more metabolizable energy and crude protein than required by their own ruminant stocks, the feeds produced by $\mathrm{HH}$ farms covered only a third of their stock requirements. Despite their limited farm size, the $\mathrm{HH}$ farmers took an active part in the commercial farming sector, for example, through the purchase of inputs for cattle and crop production and the sale of produces. The HH farms also generated higher relative 
crop yields than their LS counterparts, while cattle productivity of both was comparable, albeit low. Despite the present differential support from the government to promote medium scate LS farms, for the time being, HH farms are the main dairy cattle producers. The present findings can be considered as a benchmark to monitorfor future development in the livestock sector and as a source of information for directing improvements in feed supply, animal health and husbandry.

Keywords: feeding systems, irrigated mixed systems, Khorezm, livelihoods, stover, straw

\section{Introduction}

The farming systems in the irrigated drylands of Central Asia still struggle to adapt to the major changes caused by the breakdown of the Soviet Union in 1991. With the collapse of previous arrangements on trade and economic linkages for production and marketing of farm products, the five Central Asian republics, Kazakhstan, Kyrgyz Republic, Tajikistan, Turkmenistan and Uzbekistan face the task of developing a selfreliant agriculture for food security and improved livelihoods including for the newlyemerged, small-scale farms. In contrast to other countries of the former Soviet Union, the transition period from a command to a more market-oriented economy in Uzbekistan was not accompanied by a drastic decrease in the number of ruminants, and cattle numbers remained apparently rather stable (Iñiguez et al., 2004). The recurrently reported decline in cattle productivity after independence (1990-1998) was due to a decline in milk production per cow (Suleimenov and Oram, 2000). This in turn was attributed to the deterioration of supporting services to the livestock sector and the lack of skilled livestock farmers who had not been prepared for a change to independent farming entrepreneurs (Iñiguez et al., 2005). However, no detailed information was provided to back-up these conclusions.

After independence in 1991, the agricultural sector in Uzbekistan was characterised by large governmental farms. These cooperatives (in Uzbekistan called Shirkats) were the direct, legal successors of the kolkhozes and sovkhozes (collective-owned and stateowned large farms, respectively), which formed part of the Soviet Union agricultural production strategy (Djalalov and Gemma, 2003). However, even before independence 
and the land reforms, a large number of very small household farms existed in parallel to the large farms with private ownership of small parcels of arable land and livestock that have remained with little changes. Few years after independence, the government intended to transform Shirkats into medium-scale peasant farms for which legal framework and training programmes had especially been elaborated (Lerman, 2008a). This worked out for crop peasant farms, however had little effect on livestock keeping.

Although a proper management of livestock usually was a key element of the nation-wide reform programmes, up-to-date, reliable and comprehensive information on livestock farming, essential to support sound decision-making, did and still does not exist. For example, as compared to crop farms, the different supporting programmes suggested for livestock farms did not include highly needed subsidies and credits (Suleimenov and Oram, 2000), but focused, driven by the Presidential Resolution 308 in 2006, on increasing the number of outlets, service points and organizing auctions (Lerman, 2008a). Hence, the current predominantly small-scale livestock farming structure over entire Uzbekistan is a response of livestock holders to the policies that have been restructuring the entire agricultural sector to meet food security and adapt to a market economy, but details on the adaption of the livestock sector to these changes are scarce (Suleimenov and Oram, 2000).

Until today, the agricultural sector of Uzbekistan contributes substantially to Gross Domestic Product (GDP), for instance 22\% in 2007, from which almost half was generated by the livestock sector (Yusupov et al., 2010). Separated values by livestock species are not reported. Yet, since there are only twice as many sheep and goats as compared to cattle and one head of cattle produces absolutely more than sheet or goat, we assumed that cattle contributes most to livestock production value. Recent reports underlined that during the Soviet Union era about half of the cattle stock was reared by household farmers (Lerman, 2008b) and this tendency continued after the reforms and irrespective of the regions in the country. For example, in 2011, about $90 \%$ of cattle in the Khorezm region of Uzbekistan were reared by household farms ( $\mathrm{HH})$ and not more than about $10 \%$ by privately managed, livestock farms (LS) (State Statistics Committee of the Republic of Uzbekistan, 2011). The situation is similar for horses, sheep and goats, and poultry of which 83,80 and $60 \%$ are kept by HH farms, respectively (State Statistics Committee of the Republic of Uzbekistan, 2011). Nevertheless, the HH farms 
are per definition small-scale and the tenure for their small area is a life-long inheritable possession whilst "livestock farms" are of medium-scale and in fact mixed croplivestock farms that produce at a commercial scale with land under long-term leases of 10 to 50 years (Yusupov et al., 2010). Aside from such general knowledge, the impacts of land reforms imposed during the past two decades in Uzbekistan on the function of the different livestock species, the range of productivity, husbandry practices and main constraints of production have not been studied. Therefore, mainly broad information is summarized in reports of local and international institutions. A recent USDA report (2011) for example underlined that insufficient feed resources and lack of land areas and turnover are both key factors impacting negatively the livestock sector in Uzbekistan. But the generalization of such bottlenecks on livestock or cattle production is insufficient for shaping and developing policies to improve livestock management, production and productivity. The availability of consistent, comprehensive and reliable data is indispensable for a better-informed decision making. The objective of this study therefore was to characterise and compare the two main livestock production systems in the Khorezm region, representative for the arid environment in Central Asia, while focusing on cattle production, since this is the predominant livestock activity. The study aimed furthermore at identifying major constraints at farm level and in turn areas for possible interventions to address these constraints.

\section{Implementation of the farm survey}

\subsection{Study location and selection of farms}

The study was part of a long-term research programme on economic and ecological restructuring of land and water use in the Khorezm Region, located in the northwest of Uzbekistan between $41.1-42.0^{\circ} \mathrm{N}$ and $60.0-61.4^{\circ} \mathrm{E}$. This region is part of the Aral Sea Basin, typical for the irrigated agricultural production systems and received little international research attention before. Khorezm has a cold desert climate (BWk according to the Köppen classification; Müller, 1996) and is part of the irrigation schemes developed since centuries along the Amudarya River. In 1916, Vavilov (1997) described the Khorezm region as a geographically isolated oasis, typified by short vegetative periods due to its dependence on melting snow from the mountains in neighbouring Tajikistan, with major crops being melons, cereals, cotton, and alfalfa as a 
dominant forage crop. Nowadays this region has turned into a larger network of canals, districts and towns, reaching an area of ca. $6,300 \mathrm{~km}^{2}$ and a population of about 1.55 million (State Statistics Committee of the Republic of Uzbekistan, 2010). With about 245 people $\mathrm{km}^{-2}$, the region is densely populated. About 270,000 ha can be used for irrigated agriculture on soils that are silty-loamy (Akramkhanov et al., 2012) with weak to strong salinity of the upper soil (Tischbein et al., 2012).

The study applied a stratified random sampling strategy. The ten administrative districts of Khorezm region were stratified according to statistical data on resource endowment and livestock assets. Hence various characteristics were used such as overall cattle density; number of cattle per HH farm; overall small ruminant density; small ruminant number per $\mathrm{HH}$ farm; average size of farms; proportion of forage area to overall cropping area; people per $\mathrm{HH}$ farm; and the location of a district regarding the irrigation infrastructure. To reflect the full range of farming conditions, the statistical value for each district was ranked as low, average, and high in relation to the average value of the region. The district showing the highest number of values above average was selected (Urganch) as being representative for favourable resource endowment. Urganch was contrasted with the district with the lowest number of values (Gurlan) representing poor resource endowment and with three districts with average values (Kazorasp, Khushkupir and Yangiarik).

The number of LS farms in the sample was chosen relative to their total number in each district (14 in Urganch, 12 in Gurlan and 10 each from the others, summing up to 56 LS farms) (Figure 1). The sample farms were randomly selected from an inventory list provided by the district authorities. A cluster scheme was applied to select HH farms. Two villages per district were chosen randomly from the inventory list from which 5 or 10 households were visited, covering about $0.5 \%$ (80 farms) of all $\mathrm{HH}$ farms in the five districts.

$$
<<<\text { Please insert Figure } 1 \text { here }>>>
$$

\subsection{Data collection and analyses}

Household surveys: The interviews were conducted in the Uzbek language from December 2007 to June 2008 using a questionnaire with mainly closed questions. A pre-testing was completed with two LS and two HH farms not included in the final 
sample. Data was collected on family structure, hired farm labour, crop cultivation, livestock population, livestock products, animal purchases, feeding and fattening practices, seasonal feed usage, animal health and hygiene, and farm equipment. The farms were visited once, fully relying on a recall, and therefore the data might lack accuracy and completeness.

Data aggregation, units, feed values and animal requirements: Cattle of different age and sex classes were transferred into livestock units (LU) to increase comparability of livestock herds across the farms and for calculating feed demand ( $c f$. annex). Prices by district were provided by the Statistical Department of Khorezm. The monthly data for February to June 2008 were averaged to derive means per district. In case market prices were not available, for example for sunflower stems, prices of similar products were used as proxy. Home-consumed milk products were priced at the specific market prices declared by the interviewees. Feed importance was ranked by the farmers interviewed according to the amounts fed by them. A weighted score of importance for each feed was next calculated. The feed values and requirements of ruminants were estimated using literature data as outlined in the annex. Livestock species such as poultry and equines were not considered in the protein and energy requirement calculations because of their small total numbers compared to ruminants.

Statistical analyses: Descriptive statistics were completed focusing on identifying comparisons among the two livestock systems. The Pearson coefficient was applied for correlation analyses.

\section{Comparison of private livestock and household farms}

\subsection{Farm resources}

By definition, the two farm types differed in the size of cultivated areas. While the $\mathrm{HH}$ farms owned on average a fifth of a hectare, the LS farms cultivated more than 100 times this area (Table 1). The average household size in the $80 \mathrm{HH}$ farms was 7 persons (range 2-16), generally forming a nucleus family. Their calculated potential workforce in adult equivalents (AE) was 5.1 (range 1.6-10.5), but not all household members participated in farm activities. The nominal on farm labour force in AE was 3.0 (range 0.8-7.3) in the $\mathrm{HH}$ farms, although participation did not necessarily imply full time engagement. The average household size in the LS farms was 10 (range 3-32), 
indicating that some young families stayed with their parents on the farm after marriage. An overall family labour force of 7.0 AE (range 2.5-24.6) was calculated, from which on average 5.1 participated in on farm work (range 1.0-20.5). Thus, 59\% of the total labour force of $\mathrm{HH}$ farms was at least part-time employed on farm, while this was $73 \%$ in LS farms, suggesting that off-farm employment was slightly more important to the HH farms.

\section{$\langle<<$ Please insert Table 1 here $\gg>$}

The permanent wage labour force of the LS farms was differentiated into the categories of "farm owner" as the main decision maker, "accountant" and "production manager" as assistants to the owner, and the "workers", namely general worker, tractor driver, milking personnel, livestock worker, field crop worker, and guard. The positions were filled by family labour force, in particular the more qualified categories, or other wage labourers. On average, 1.7 AE per farm was employed from outside the farm. Considering the share of non-participating farm labour force, the gap could have been filled by family labour, suggesting that those people preferred other jobs over farming, were more qualified for other jobs or were earning more elsewhere.

Besides the permanent labour, the LS farms hired labour daily when needed. Fifty out of the 56 LS farms surveyed did so, and the number of labourers hired over the year varied between 2 and 50. Since the number of days could not be recalled, the total labour force including day wage labour could not be calculated.

In the HH farms, males between 16 and 60 year-old usually deal with fodder storage and feeding issues, whereas the women of the same age usually milked cows and fed animals. However, dealing exclusively with livestock was an exception; livestock was often considered secondary, as expressed in labour allocation (Table 1). Members of $\mathrm{HH}$ families from 60 year-old onwards usually deal with supervising livestock keeping, advising young people and partly helping in feeding. Males and females between 7 and 16 year-old usually perform feeding and watering of poultry, watering other animals and eventually helping elders in feeding cattle.

Absolute livestock numbers differed significantly between both livestock keeping systems, though the winter housing area allocated per cattle livestock unit was similar (Table 1). As expected, differences were found in the machinery use and ownership; LS farms clearly owned more tractors, pumps and other agricultural 
implements, though not all farms possessed these implements. Permanent labour force per area was much higher in $\mathrm{HH}$ farms, which explains the finding that these farms utilise much more manual work as having less machinery. The cultivated area relative to cattle herd size in the LS farms was 8 to 10 times that of $\mathrm{HH}$ farms, pointing to a special feature of this latter farm type.

The Pearson correlation coefficient of area cultivated in ha and cattle in LU was $0.79(\mathrm{P}=0.0001)$ over the two systems $(\mathrm{n}=134)$. By system, the correlation was significant at $0.58(\mathrm{P}<0.0001, \mathrm{n}=55)$ for $\mathrm{LS}$ farms, while it was only $0.19(\mathrm{P}=0.0854$, $\mathrm{n}=79$ ) for HH farms. Thus, in the LS farms the number of cattle was clearly linked to the cultivated area. This is in line with a decree of the Cabinet of Ministers (2003), which imposed a ratio of livestock to land area for LS farms (9 ha minimum, 0.3 ha per "nominal cattle" in Khorezm - the Uzbek "nominal cattle" unit is calculated as cattle (cows and bulls) and horses equalling 1, calves 0.6 , sheep and goats 0.1 , pigs 0.3 and poultry 0.025$)$. However, the ratios evolved and nowadays differ from the initial ratios estimated during farm establishment.

\subsection{Livestock inventory}

The HH farms showed a smaller range of cattle numbers (1-13 versus 4-131 in LS farms), although the coefficient of variation was similar (Table 2). In LS farms, cows made up $33 \%$ of total cattle head, calves $18 \%$ and yearlings $16 \%$ (Table 2). The distribution of animal classes in $\mathrm{HH}$ farms was similar with $36 \%$ cows, $26 \%$ calves and $15 \%$ yearlings. However, mating bulls were non-existent in the small $\mathrm{HH}$ farms, while the bull:cow ratio in LS farms was 1:21. The shares of non-fattening and fattening bulls in LS farms were both $16 \%$, while those in $\mathrm{HH}$ farms differed with $8 \%$ and $15 \%$, respectively.

\section{$\ll<$ Please insert Table 2 here $\gg>$}

When asked to compare their current numbers of milking cows with those of previous years, from 55 LS farmers, $29 \%$ replied keeping a steady number of milking cows, $24 \%$ were keeping a smaller number than before, while almost half of the farmers reported to have increased the number of their milking cows. A slight trend to increase the cattle stock was also recorded at the national level (FAO, 2010). 
The survey was purposefully restricted to cattle owners. While poultry was kept by more than $80 \%$ of $\mathrm{HH}$ farms (on average 20 birds per farm, range 3-500), only half of the LS farms raised them, though on average 137 birds (range 20-540). Twentyfive $\mathrm{HH}$ farms owned other poultry species such as ducks and turkey, from which they kept on average 7 birds (range 1-51). Sheep were part of both systems, albeit more prominent in LS farms. The average head counts per farm were significantly higher in the LS farms (26 versus 4 head). A few LS farms only kept goats. One single LS farm had eight pigs. Donkeys were reared only by HH farms, while more LS than HH farms kept horses.

\subsection{Crop and forage production}

In terms of monetary and in-kind gross benefits (home consumption and feeds), crop production came surprisingly first in the LS farms with $71 \%$ versus $29 \%$ from cattle production. This was very different in the HH farms, where both had an equal share, with a slight lead of cattle production contributing $52 \%$.

Total cropland by farm was reported as "cultivated area" (see Table 1). When summing up the areas allocated to each crop as reported by the farmers, the total "allocated area" was slightly smaller than the cultivated area in LS but larger in HH farms. The allocated area was taken as a base for crop and forage production. The share of feeds was high with $48 \%$ of total value of crops produced in LS farms and still $32 \%$ in $\mathrm{HH}$ farms. Therefore, producing feeds is presently an important output from field crop activities, which indicates the present level of integration of crops and livestock within the farming systems. The cultivated crops are accounted in the feed types either as crop by-products or as explicitly grown forages.

Fertilizer expense per ha was $57 \%$ higher on $\mathrm{HH}$ farms than on LS farms. HH farms had accordingly higher expenses per ha allocated, but generated more harvest value per ha when monetised (71\% more on HH than on LS farms; Table 3). Besides the relatively higher input of mineral fertilizers, $\mathrm{HH}$ farms also had more manure per ha than their LS counterparts. On the cost side, HH farms allocated relatively more family labour (with unknown opportunity costs) while the LS farms had to cover not only family but also wage labour and higher machinery costs.

$$
\ll<\text { Please insert Table } 3 \text { here } \gg>
$$


By law, the LS farms had to sell $2,000 \mathrm{~kg}$ of wheat per ha annually to the government. Each LS farmer had to individually negotiate the number of ha to be allocated to wheat and to cotton with the district branch of the Regional Agriculture and Water Administration office. The remainder of the harvest can be marketed at local markets at free market prices or consumed (Rudenko et al., 2012). The government price did not differ between districts and was on average about a fifth of the market price. Cotton production was similarly mandatory for LS farms (70\% of the yield to be sold to the government) whereas $\mathrm{HH}$ farms were exempted from this rule.

\subsection{Feed types, sources, volumes and their nutritional value}

Only three LS farms had access to rangeland for grazing their cattle. More frequently, cattle (in 12 LS farms with slight differences across seasons) grazed vegetation near canals, lakes, riversides, and forest margins. Grazing stubble ranked second in importance (12 LS farms but mostly in autumn and winter). Some fallow land was also grazed. In spring, summer, autumn and winter, $36 \%, 44 \%, 55 \%$ and $47 \%$ of all LS farms used one or several types of grazing area, respectively. The interviewed farmers declared the contribution of grazing to feeding as "important". The feed quantities consumed and nutritional qualities from grazing could not be assessed during the recall.

Relatively more LS farmers $(n=28)$ grazed their sheep, namely $61 \%, 57 \%$, $64 \%$ and $64 \%$ in spring, summer, autumn and winter, respectively. Sheep mainly grazed vegetation at canals, borders and other marginal areas. Grazing stubble was widely reserved for cattle. The one LS farm that kept 120 sheep had over 160 ha rangeland, which was used year-round, but stated of being of poor-quality.

In the $\mathrm{HH}$ farms $(n=79)$ grazing areas for cattle were rare. Stubble from cropped fields were mainly available in autumn $(n=18)$ and winter $(n=8)$. Second was grazing vegetation along canals and other borders. Rangeland was not available at all. By season, $11 \%$ of all $\mathrm{HH}$ cattle farmers grazed their cattle in spring, $16 \%$ in summer, $33 \%$ in autumn and $16 \%$ in winter. A similar pattern was observed by the HH sheep farmers $(n=24)$.

Hand feeding was the rule and the relevant feed types included agro-industrial by-products, straw and hay, forages, grains, and vegetables. Agro-industrial by-products 
were fed to cattle by all LS farms except one $(n=54)$, while $95 \%$ of $\mathrm{HH}$ farms did so. The most commonly fed by-product was cottonseed cake 2 (from the second pressing; importance index 5.1 for LS and 5.0 for HH farms), which were used by almost $90 \%$ of both farm types (Table 4). Few farms purchased mixed concentrates (index 0.2 in LS farms) and even less farmers fed minerals (index 0.1 in LS farms). It was common to provide two or three different by-product types.

\section{$<<<$ Please insert Table 4 here $>>>$}

All cattle keeping LS farms, and $98 \%$ of $\mathrm{HH}$ farms, fed their cattle with straw or hay. Wheat straw was the most widely used. Feeding cultivated forages was omnipresent in LS farms and used by $88 \%$ of $\mathrm{HH}$ farms. The primary forage by rank was green fodder maize (index 2.6) in the LS farms. Sorghum dominated in HH farms. In $71 \%$ of LS farms, grains were one component of cattle diets, though, in $\mathrm{HH}$ farms this was only $38 \%$. The most important grain in both farm types was broken rice after polishing. Vegetables (mainly carrots, beets and pumpkins) were feed components in $73 \%$ of LS and $70 \%$ of $\mathrm{HH}$ farms (however, only a sub-sample was asked this question). Among the agro-industrial by-products, cottonseed needed to be purchased, while the wheat and rice hull and bran stemmed mostly from own production. Grains originated from the farm, as were the forages, straws and hays. Some farms reported to have purchased wheat straw.

The quantities of feeds produced on farm were contrasted with the estimated feed requirements (Table 5). In the LS farms, the requirements (here calculated over all ruminants, but by excluding the less frequent equines and poultry) were on average clearly met by the farm-produced stovers, straws, grain products and forages. The rates of oversupply $(\mathrm{n}=55)$ of ME $(155 \%)$ and CP (160\%) were similar, and increased to $174 \%$ for both when purchased feeds were included. However, the calculated supply does not account for spoilage from storage and therefore the real quantities available might be lower.

\section{$<<<$ Please insert Table 5 here $>>>$}

The situation in the $\mathrm{HH}$ farms $(\mathrm{n}=77)$ differed significantly with only $32 \%$ of ME and $26 \%$ of CP requirements being covered by farm-produced feeds. Purchased feeds partly covered the gap, 59\% of ME and 57\% of CP. Cottonseed cake, cotton husks, wheat straw and green sorghum fodder were the main registered purchases. An 
unregistered quantity of feeds was received as in-kind income from wage labour. While workers generally received a minimum wage, these additional in-kind payments represented an additional bonus. Forty-four per cent of $\mathrm{HH}$ farms had either a family member working in another private farm (38\%) or were running themselves such an additional farm (14\%). Additionally, an unregistered number of $\mathrm{HH}$ farm members were hired sporadically as casual workers on private farms. This happened particularly at harvest times and workers generally accepted part of their wage in form of grain or straw, generating extra fodder for their livestock.

Besides the quantities of collected feeds, such as cane, liquorice and camel thorn, which were included in the feed supply, cattle and sheep also grazed canal sides, further complementing the diets. Hence, the $\mathrm{HH}$ farms are highly integrated with the larger private farms as they rely substantially on feeds produced outside their farms.

The composition of the recalled hand-fed diets showed a similar trend in the two systems. Based on dry matter, ruminants in the LS and HH farms, respectively, received a diet of $67 \%$ and $69 \%$ straws, stovers, husks and hay, $22 \%$ and $14 \%$ green fodder and silages, and $11 \%$ and $16 \%$ grains, cake, hull and bran. The magnitude of the existing contribution of grazed canal sides and in few cases rangeland could not be assessed here. Figures from Uzbekistan as a whole from the early 1990s gave an average of $34 \%$ range grazing, 38\% grains and other concentrates, and $28 \%$ crop residues and forage crops (Nordblom et al., 1997). This assessment combines different species and agro-ecological zones. The striking difference in our study is the much higher contribution of roughages and lower proportion of grains and other concentrates.

The cropping pattern in LS farms is still driven by mandatory state quotas (Rudenko et al., 2012). At least 10 ha (farmers have to negotiate their specific contracts) are to be allocated to cotton and wheat (Yusupov et al., 2010) that explains the relative dominance of these crops despite their less favourable returns (Table 6). The proportions of feed values to total crop values emphasize the crops' multiple uses with nominal revenues beyond fibre and grain. Especially for the LS farms, these feeds are important inputs to their livestock sectors or are used as in-kind payments for wage labourers for feeding livestock at the $\mathrm{HH}$ farms. Maize reached the highest feed value contribution to total crop value $(30 \%)$ with a high stover:grain yield ratio of $5: 1$. Rice produced not only straw for feeding but also hull and bran and crushed grain. The 
straw:grain ratio of wheat was relatively low according to the recall data. Nowadays, cotton stover is mainly used as a fuel; formerly it was widely used as a feed component. The by-products from cotton processing had to purchased back by the farmers. They are, therefore, not accounted for in the above calculations of farm-produced feeds, but formed an important part of balancing proteins in the diet.

$$
<<<\text { Please insert Table } 6 \text { here }>>>
$$

The price ratio of straw to grain is a further indicator for the economic value of multifunctional crops (Schiere et al., 2004). Cotton showed a ratio of 0.18, maize 0.10, wheat 0.08 and rice 0.05 . Thus, except a high ratio for state-contracted wheat with 0.44 , the ratios were relatively higher for stovers than for straws, in line with the higher feed value contributions of stovers compared to straws. This is a general phenomenon observed, emphasizing the special importance of stovers in mixed farming systems (Schiere et al., 2004).

\subsection{Cattle performance and system productivity}

Calving percentage was reported at $74 \%$ in LS and $68 \%$ in $\mathrm{HH}$ farms. According to the recall, annual cattle mortality was low. Adult mortality was reported with $1.8 \%$ in LS ( $\mathrm{n}=2018$ head) and $3.9 \%$ in HH farms ( $\mathrm{n}=230$ head) for the previous twelve months. No calf losses were reported for $\mathrm{HH}$ farms ( $\mathrm{n}=82$ calves), while a very low calf mortality of $1.8 \%$ was reported at LS farms ( $n=453$ calves). Main reasons for the death of adult cattle were cold stress (two thirds of deaths occurred in wintertime), related to calving and to accidents in LS farms. In few cases in both systems, foot-and-mouth disease-like symptoms caused deaths, while some $\mathrm{HH}$ farms reported insect bites as the cause of the symptoms. Calves in LS farms died from cold stress and diarrhoea. In general, $40 \%$ of LS farms and $32 \%$ of $\mathrm{HH}$ farms experienced cases of cattle disease during the previous year.

The products notably derived from cattle included milk, meat, manure and hides. The use of draught power was not mentioned. Whether or not milk or meat contributed more to the benefits depended on the farm type (Table 7). While in the monetary revenue structure meat clearly outperformed milk in the LS farms, the difference between the two was statistically not significant within the HH farms. In the latter, the high importance of milk was evident through the value of home-consumed 
dairy products, which was comparable to the total dairy product sales in this system. Comparatively, benefits from manure and hides were less important when monetized. Thus, overall, cattle production was multi-purpose, while the dual-purpose prevailed; $\mathrm{HH}$ farms were more milk-oriented than LS farms, while LS farms were relatively more meat-oriented.

$<<<$ Please insert Table 7 here $\gg>>$

Fifty-four of the 56 LS farms milked their cows, yielding 46 litres a day per herd $(\mathrm{SE}=5)$. Almost all LS $(\mathrm{n}=51)$ that milked cows, consumed a part at home, on average 17 litres per day ( $\mathrm{SE}=2)$. Milk production was much lower in the $\mathrm{HH}$ farms, on average 5.4 litres a day $(\mathrm{SE}=0.4)$. The major part of it was home-consumed (4.7 litres, $\mathrm{SE}=0.3$ ), while the remainder sold to neighbours. The milk price differed between the two systems; the median price was 350 UZS per liter (or about 0.28 USD per liter) in LS and 420 UZS per liter (0.34 USD per liter) in HH farms.

Milk processing with subsequent sales was more often reported in LS than in $\mathrm{HH}$ farms. Eleven out of $56 \mathrm{LS}$ farms processed milk, from which five were producing a single dairy product and six produced two. Home consumption of dairy products, particularly yoghurt, was reported in $70 \%$ of $\mathrm{HH}$ farms. The quantities could, however, not be assessed by recall and therefore the benefit from value added could not be calculated.

Cattle meat production was almost exclusively for sale. Home slaughtering for own consumption and sales to neighbours or relatives occurred only occasionally and was not recorded during the study period. Cattle were mainly sold alive at markets or to butchers. Therefore, hide sales played a minor role, which exclusively occurred in Kazorasp district. The average amount of cattle manure produced per farm was $148 \mathrm{Mg}$ year $^{-1}$ and the majority used it entirely on farm. Only five LS (out of 54) sold manure, on average $100 \mathrm{Mg}$ year $^{-1}$. Twelve LS farms also purchased manure. On average, they spent 548537 UZS (SE=236107; or the equivalent of 439 USD, SE 189 USD) for 116 $\mathrm{Mg}$ of manure annually. The spread in revenue among farms was very high as indicated by the high standard error of the means. The coefficient of variation from the annual monetary revenue from meat and live animals was $131 \%$ and that from all milk products was $106 \%$. 
Cattle productivity was estimated as average daily milk yield (excluding the milk drunken by calves) per number of milking cows, and as annual revenue (monetary and valued in-kind) from cattle products divided by the milking cows (in case of milk products only) or livestock units per farm (Table 8). The average milk yield per cow differed significantly between the farm types (Table 8). Dairy products sold per milking cow were not significantly different, though only $22 \%$ of cow milking $\mathrm{HH}$ farms sold dairy products, with a high variation among farms. The total products derived per milking cow (thus sales plus home consumption) showed higher relative benefits for LS farms. However, when comparing total products derived per cattle LU, then the two systems were equally productive.

$<<<$ Please insert Table 8 here $>>>$

\subsection{Availability of livestock services}

The Livestock Production Departments at the district branches of the Regional Agriculture and Water Administration are currently the main bodies administrating livestock production. The District Veterinary Administration also reports to this Department, which organises training courses for LS farmers, or sends them to other institutes for training. In line with this, the survey findings showed that every village has its own private village veterinary centre, reporting to the District Veterinary Administration. The LS farmers make individual contracts with either the district branch of the Administration or their village centre. The private village veterinary centres are responsible for dealing with livestock diseases and deaths at both the LS and $\mathrm{HH}$ farms of their respective region. Several vaccinations, among which against footand-mouth disease, are compulsory and provided free of charge during state campaigns, though veterinarians receive a fee for their services. The village veterinary centres also provide other private paid services, i.e. emergency helps, artificial inseminations, consultations to LS and HH farms when needed. Hence, veterinary services were readily available to LS and HH farms. A veterinarian cured almost all sick cattle reported by LS farms, corresponding to $1.9 \%$ of cattle in the studied population. In the $\mathrm{HH}$ farms, a veterinarian also mainly treated animals, although in rare cases treated by the family.

An organised breeding system that provide the farms and households with high yielding cows on a regular basis does not exist yet in Khorezm but does in other 
parts of Uzbekistan. The regional administration in Khorezm region mainly relies on imports of cows (Khorezm Regional Administration, 2009), e.g. 1156 improved cattle were sold in auctions and 650 head were imported from Ukraine in 2008. Consequently, artificial insemination was not common except in only $17 \%$ of LS farms $(n=52)$. Of those who used it, three reported one service per conception, four conceptions in 20 to $90 \%$ of cows after first service, one unsuccessful conception, while one did not answer the question. The use of artificial insemination was even lower in the $\mathrm{HH}$ farms $(6 \%$, $\mathrm{n}=79$ ); most reported that half of the cows conceived after first service.

During the time of the field survey, several LS and HH farmers mentioned difficulties in buying feeds. The only regional commodity purchase point in Urganch city was too distant for many farmers and was only open during auctions. In the second half of 2008, 11 district associations and 99 trade centres were established to fulfil the Resolutions of the President of the Republic of Uzbekistan (2006 and 2008) in supporting animal production in LS and $\mathrm{HH}$ farms and improving respective service institutions. The new organisations produced by-products (especially cottonseed cake, cotton husk and mixed concentrates) to improve the access for livestock producers. However, quantities sold in 2008 were still limited when compared to the "nominal cattle" units, and the products were not continuously available.

\section{Discussion and scope for improvement}

The aims of the Uzbekistan government's livestock development programme are to increase the number of farms keeping livestock, to improve livestock productivity, and to raise rural family incomes (Lerman, 2008a). No detailed numbers of Uzbek livestock production in general and cattle in particular exist and those that are regularly used in reports (e.g. the recent USDA report) are aggregates for Uzbekistan, which do not always match the ones in the study region Khorezm. Moreover, the reforms of the sector primarily addressed medium-scale farms but the widespread $\mathrm{HH}$ farms remain a backbone of the sector, which is nearly untouched by the developments. In 2006, about 17,000 peasant farmers in Khorezm had access to a total area of 222,223 ha. Of these farmers, less than $4 \%$ (700) had been registered as livestock farms rearing only 24,000 head of cattle. At the same time, official numbers indicate that the about $207,300 \mathrm{HH}$ farms in Khorezm had 48,866 ha of land to hold about 478,000 head of 
cattle (Djanibekov, 2008). Hence, both Müller (2006) and Djanibekov (2006, 2008) postulated that the private plots are simply insufficient in size to produce the necessary quantity and quality of feed, which often resulted in farmers using the sparse halophytic vegetation on fallow land for a free-of-charge roaming (Iñiguez et al., 2004), underlining that cattle production is hampered by a lack of feed (USDA, 2011).

On the other hand, indirect evidence indicated that the livestock sector ranked second after cotton as the most important economic sub-sector within the agricultural production sector (Müller, 2006), with almost $50 \%$ of agricultural value generated in the livestock sector. Not only the livestock sector was assessed as being an important pillar of livelihood security in the region but Bekchanov et al. (2012) argued furthermore that an increase in livestock productivity is likely to increase national and regional incomes much more than what could be expected through cotton market liberalization and upgrading crop production efficiency. Without being aware of or having an understanding of the bottlenecks in the livestock production sector, the formulation of efficient policies becomes quite challenging. Even though findings formulated in the reports sound convincing, they are based on unreliable and incomplete, official data. These can nevertheless be informative to some extent and could provide the basis for some conclusions. Yet various conclusions based on official statistics do not always comply with the detailed findings from the Khorezm region. Hence, from many perspectives, the findings of this study can be seen as a benchmark to monitor future development in the livestock sector and as a source of information to design improvements in feed supply, husbandry and animal health.

Both farm types examined were diversified concerning animal species reared and produced and used a wide range of feeds including crop by-products and forages. The area of forage is however declining, as more land in Uzbekistan is being allocated to cereals (Suleimenov and Oram, 2000), which had also been concluded for the study region (Djanibekov et al., 2013). This in turn increases the quantities of cereal straw in the animal diet, but cereal straw has a much lower nutrient density than typical forage crops (Djumeava et al., 2009). The LS farms were nevertheless able to meet the requirements of their animals. The importance of purchases of cottonseed as feed illustrates that livestock is not only integrated into crop production on farm but also regionally via the cotton processing factories and trade centres and via linkages with 
private farms as previously suggested (Rudenko et al., 2008). However, as postulated before (Rudenko et al., 2008), the farmers interviewed were subjected to restrictions in buying agro-industrial by-products, and special prices were applied to different portions.

In contrast, as expected, the very narrow land:cattle ratio in the $\mathrm{HH}$ farms inhibited the match of cattle feed demand and farm-grown feed resources as evidenced by the detailed estimates. More than two thirds of the required feed by $\mathrm{HH}$ farms was compensated for by external sources from outside the farm such as by stover or straw from private farms received as in-kind revenue for wage labour which has become a common practice in the region (Djanibekov et al., 2013), or through grazing along irrigation canals and purchased feeds. A similar link between the agricultural labour market and straw in-kind payments was reported for the northern plains of India (Erenstein and Thorpe, 2010). Since the HH farms keep the majority of cattle in the region, comprehensive feed budgeting should be performed at regional level. The safety and sustainability of access to these feed resources should be analysed from an institutional perspective. Furthermore, the present feeding habits call for studies to identify economically feasible options for improving present feeding practices, additional in-depth seasonal monitoring of the quantity and nutritional quality of the cattle diets would be required along with identifying the determinants of diet selection by farmers as has been suggested previously (Djanibekov, 2006). Such studies should also aim at identifying untapped locally available feeds, fallow lands, and look into options for rotations or intercropping of cash crops with feeds, or agro-industrial byproducts.

Future cereal cropping studies in the region are challenged to develop a systems approach and aim at fully understanding the multiple and competing uses and relevancy of young plants, straws and grains in animal feeding (Schiere, 2010). Intercropping of cereals with legumes may increase the nutritional quality of stubble grazing, which has a high importance in cattle diets in the region (Djanibekov, 2008). Yet, feasibility and water demand of such cropping practices should be assessed ex ante since water availability in the Khorezm region is predicted to become scarce (Tischbein et al., 2012). However, at the time of the survey, intercropping of wheat with other crops was not allowed, although options do exist to practice summer cropping after the 
harvest of wheat (Devkota et al., 2013). Along with incentives to improve the quality of agro-industrial by-products, and the search for additional feed sources, the inclusion of high quality tree foliage has a certain potential (Djumaeva et al., 2009), although the labour resources for collecting tree leaves should not be underestimated.

Although the $\mathrm{HH}$ farms generated higher crop revenues per ha, cattle reproductive parameters were comparably low in both livestock farming systems, as were total products derived per cattle LU. Milk yields were low in both HH and LS farms. This could be due to the low genetic potential combined with the little scope for selection within the relatively small herds, and little use of artificial insemination due to an apparently weak organisation of breeding in the region. Another important reason for the low cattle reproduction is the imbalances and deficiencies in the diet, e.g. the lack of mineral supplementation, which is considered as a reason obstructing livestock production (USDA, 2011). Indeed, the quality of the cattle feed in the region is notoriously low (Djumaeva et al., 2009) and the high proportions of untreated maize stover, and wheat and rice straw in the diet undoubtly has limited dry matter intake. Including urea treatments may be a feasible intervention in such cases (Schiere, 2010), but have not been explored yet.

As expected, both systems differed in the proportion of monetary benefits and benefits from on farm consumption; the proportion of the internal use of products was much higher in the $\mathrm{HH}$ farms, $54 \%$, compared to only $16 \%$ in the LS farms. The share of livestock production is likely to increase when including other livestock species. Previous net benefits reported, not calculated here, suggest a lower overall contribution from crops to farm net income than usually postulated (e.g. Djanibekov, 2008). Crop benefits include livestock feeds, which form an internal input to livestock farming and hence this may balance some feed costs when calculating overall net farm benefits. HH farms are regarded also as too subsistence oriented by the government, especially regarding cow milk. Considering however the number of farms and the absolute quantities they produce, their contribution to commercial markets becomes evident (Lerman, 2008b), a finding confirmed by the present study, although only a quarter of HH farms sold milk. The others preferred home consumption. This might also be the most rational considering the small quantities, the necessary infrastructure and the short shelf life of the product. 
Even though most diseased animals could be cured due to the efficient veterinary services, and hence mortalities were reportedly low, there is still a need for training of farmers. Such trainings should also include the condition of stables and resulting welfare of animals, which requires an understanding of the degree of cold stress and potential low cost solutions. Begzsuren et al. (2004) reported e.g. the importance of severe winter weather on livestock mortality. In a comparable cold desert environment in southern Mongolia, these authors found that severe winter stress influenced mortality more than drought, though aggravated if a previous drought occurred that restricted adequate feeding of animals. However, their study was conducted in a pastoral system, while in Khorezm farmers provided winter barns, alleviating the cold stress as a welfare issue to some extent. According to Suleiman and Oram (2000), barns are supposed to be heated during winter but recurrent power failures are still causing high livestock mortality rates. Overall, the high variation among farms suggests a broad potential for improving livestock keeping and income generation of the rural population as previously postulated (Djanibekov, 2008; Djumaeva et al., 2009). Longer-term studies, such as farm monitoring of animal productivity, access to resources, cost-benefit analyses and objectives are desirable to identify constraints and priorities in more detail. The latter may largely differ between private farms, at regional and national levels. A next step would be a prioritization and coordination of actions and policies that support the further development of the cattle sector. This would also imply evaluating the pros and cons of sustaining the dual-purpose of wheat production (Kienzler et al., 2012) or a specialized cattle production.

Due to the limited total income caused also by the very restricted land area, HH farms could be classified as semi-subsistence farmers. Such farms form a very heterogeneous group that is also present in Central and south-eastern Europe (Fritzsch et al., 2011). While the European Union is nowadays issuing programmes to commercialise such farms, it has been discussed also whether or not they should exit farming (Fritzsch et al., 2011). In Uzbekistan, both LS and HH farms are currently benefitting from measures to improve infrastructure such as the establishment of accessible agricultural input shops. The extent and success of these measures is still to be assessed. Facilitating access to specialised machinery could be a further relevant measure to support small-scale farming. A comprehensive analysis on alternative 
income generating activities, and considering the changes in regulative measures by the government may help figuring out an optimal degree of the farms' market integration from a household perspective.

The findings showed that both livestock systems are in fact mixed farming systems, since both crops and livestock generate substantial shares of income. The share of motorised agricultural power and a conceptual specialization of the LS farms classify this farm type more toward intensive systems, while the higher self-consumption among $\mathrm{HH}$ farms suggests a more intermediate intensification level (Erenstein and Thorpe 2010). Nevertheless, the present findings combined with previous analyses from for instance Bekchanov et al. (2012) in the study region underline the potential of the livestock sector for sustainable livelihoods.

Although the LS farms have been designed to play a strong role in the national supply of animal products such as milk after the breakdown of large-scale cooperative farming, this has not materialized yet (USDA, 2011). For the time being, the HH farms seem to be the main player in the Uzbek dairy cow sector but much room for improvements exists and their development potential is crucial for regional and national income. The large variations around the means illustrate that during the reforms the livestock holders have developed in heterogeneous group. This in turn demands targeted information and training tailored to the specific needs of the livestock holders. Since the deterioration of the well-established and functioning links between agricultural knowledge and information systems and the extension and production units that existed before independence, farmers are now in a high need of extension service providers, which simply are not available anymore (Bekchanov et al., 2009). The presently existing institutions and agricultural extension service providing organizations such as universities, research institutes, NGOs, farmers' associations and rural development projects are inadequate necessitating new structures and people. Furthermore, due to the high heterogeneity of the livestock keepers, these new structures and people are welladvised to adopt a "salad bar" type of approach: let the livestock holders choose the topics they want to be taught on, and let the new organizations and staff serve them, and not the other way around. 


\section{Conclusions}

Two decades of farm restructuring in Uzbekistan has impacted the cattle sector in many ways, although much is not known. This in-depth study showed that the two dominating modes of cattle keeping have much in common but also differ in many ways. In general, small-scale cattle farming is highly integrated with crop production but suffers from low productivity. The findings can serve as a benchmark to monitor future development in the cattle sector and as a source of information to improving feed supply, animal health and husbandry. The overall findings call for a targeted support of the cattle sector based on the understanding of the differentiation between livestock holders, their potentials and bottlenecks. This would form the basis for a true development of the cattle sector that according to various studies has a higher potential to raise regional welfare and individual livelihoods than other agricultural sectors.

\section{Acknowledgements}

The financial support by the German-Uzbek Khorezm Project: Sustainable management of land and water resources in Uzbekistan - the ZEF/UNESCO project in the Aral Sea Region (funded by the German Ministry of Education and Research) is gratefully acknowledged. Many thanks to the anonymous reviewers and the editor for the very thorough review addressing all aspects of the manuscript and the helpful and supportive comments on an earlier draft.

\section{Annex}

\section{Aggregation of data and calculation of units used in the analysis}

Data were aggregated or transformed for the analyses. Manpower was expressed in adult equivalents (AE) based on conversion factors provided by the National Ministry of Agriculture and Water Resources in Uzbekistan (as cited by Djanibekov, 2008) and adapted to the existing dataset. Therefore, all females and males aged 16 to 60 were counted as 1, people older than 60 as 0.8 and youth between 7 and 15 years old as 0.5 . Actual hours worked could not be recalled .

Because animals could not be weighed during the survey and accurate information could not be gained during the recalls, animal weights had to be derived from literature. Makhmudovich (2001) stated for Uzbekistan $371 \mathrm{~kg}$ as live weight of a 
cow in 1990 and $247 \mathrm{~kg}$ in 1999. As this secondary source did not differentiate between cows from mountains or plains, an average adult live weight of $300 \mathrm{~kg}$ was assumed for the calculation of a livestock unit (LU) in Uzbekistan. Djumaeva et al. (2009) also assumed a cow live weight of $300 \mathrm{~kg}$, which is considered average in the Khorezm region. A mini survey in September 2012 involving a butcher and several livestock farmers in Urganch confirmed this estimate for adult cattle live weight (Kudrat Nurmetov, personal communication).

The livestock units (LU) were computed as metabolic live weight (kg live weight ${ }^{0.75}$ ) divided by 100 . Bulls were calculated as 0.8 , cows were entered as 0.7 , yearlings as 0.4 and calves as 0.2 . Sheep and goats were entered as 0.1 , donkeys as 0.5 , horses as 0.8 and chicken as 0.01 .

For straws, agro-industrial by-products and hay in LS farms, the percentage of farms mentioning a product as most important was multiplied by 6 as the maximum number of feed types to be ranked was 6 , the second multiplied by 5 , and so forth until the sixth ranked product, which was multiplied by 1 . The six weighted ranks have been summed up, building the overall rank index of each feed. A higher index indicated a higher importance as perceived by the farmers. Similar indices have been calculated from the four ranks assigned to forages and vegetable types and the three ranks assigned to grains in LS farms, and the three ranks for forages and two ranks for grains and vegetables in $\mathrm{HH}$ farms, where less varied feeds were offered.

\section{Estimation of feed values}

Nutritional values of feeds including dry matter, metabolizable energy, and crude protein were mainly derived from Tomme and Novikov (1963) who had analysed the feeds from the region and the National Research Council (NRC, 2001). Metabolizable energy (ME) was used for calculating ratios of all ruminant species. The energy requirement for maintenance was derived from Zemmelink et al. (1992). Increments for growth and lactation were added (Table a). No additions for "activity" were considered since grazing is uncommon in the study areas (Djanibekov, 2008). In the LS farms, on average, about $62 \%$ of cows were in milk at the test day. The average lactation length was calculated as 226 days, resulting in a lactation yield of 1,356 L. This average value accounted already for fertility rate and unproductive animals in the 
herd. The crude protein $(\mathrm{CP})$ requirements of cattle were estimated according to Preston (1966; Table a).

$\ll<$ Please insert Table a here $\gg>$

Small ruminants' requirements were calculated based on $45 \mathrm{~kg}$ LW (live weight) and $100 \mathrm{~g}$ daily weight gain. The maintenance energy requirement was computed as $0.424 \mathrm{MJ} \mathrm{kg} \mathrm{LW}^{-0.75}$, energy for growth as $0.0304 \mathrm{MJ} \mathrm{kg} \mathrm{LW}^{-0.75}(\mathrm{NRC}$, 1981), and crude protein in $\mathrm{g} \mathrm{day}^{-1}$ as $4.88 \mathrm{~kg} \mathrm{LW}^{-0.75} \mathrm{x}(1+6.64$ daily weight gain in $\mathrm{kg})$ (Preston, 1966).

\section{References}

Akramkhanov, A., Kuziev, R., Sommer, R., Martius, C., Forkutsa, O., Massucati, L., 2012. Soils and soil ecology in Khorezm, in: Martius, C., Rudenko, I., Lamers, J.P.A., Vlek, P.L.G. (Eds) Cotton, Water, Salts and Soums - Economic and Ecological Restructuring in Khorezm, Uzbekistan. Springer, Dordrecht, Heidelberg, London, New York, pp. 37-58.

Begzsuren, S., Ellis, J.E., Ojima, D.S., Coughenour, M.B., Chuluun, T., 2004. Livestock responses to droughts and severe winter weather in the Gobi Three Beauty National Park, Mongolia. Journal of Arid Environments 59, 785-796.

Bekchanov, M.B., Kan, E., Lamers, J.P.A., 2009. Options of agricultural extension provision for rural development in Central Asian transition economies: the case of Uzbekistan, in: 5th Annual Conference Proceedings Research for Sustainable Development, held by Westminster International University, Tashkent, 14th May, pp. 72-83.

Bekchanov, M., Müller, M., Lamers, J.P.A., 2012. A computable general equilibrium analysis of agricultural development reforms: national and regional perspective, in: Martius, C., Rudenko, I., Lamers, J.P.A., Vlek, P.L.G. (Eds) Cotton, water, salts and soums - economic and ecological restructuring in Khorezm, Uzbekistan. Dordrecht Heidelberg London New York, pp. 347-370.

Cabinet of Ministers, 2003. Decree No. 476, 30 October 2003, Appendix 7: Regulations of allocating land for farmers to lease for long term. Republic of Uzbekistan, Tashkent. 
Devkota, M., Martius, C., Lamers, J.P.A., Sayre, K.D., Devkota, K.P., Gupta, R.K. Egamberdiev, O., Vlek, P.L.G., 2013. Combining permanent beds and residue retention with nitrogen fertilization improves crop yields and water productivity in irrigated arid lands under cotton, wheat and maize. Field Crops Research 149, $105-114$.

Djalalov, S., Gemma, M., 2003. Tendencies in Uzbekistan farm production, in: Baratov, F., Shukurov, S. (Eds) Uzbekistan Economy: Statistical and Analytical Review. Centre for Effective Economic Policy, Tashkent, pp. 84-90.

Djanibekov, N., 2006: Cattle breeding systems in dekhkan households. Agriculture in Uzbekistan 4, 25-26.

Djanibekov, N., 2008. A micro-economic analysis of farm restructuring in the Khorezm region, Uzbekistan. PhD Thesis. Center for Development Research (ZEF), Rheinische Friedrich-Wilhelms-Universität, Bonn.

Djanibekov, U., Djanibekov, N., Khamzina, A., Bhaduri, A., Lamers, J.P.A., Berg, E., 2013. Impacts of innovative forestry land use on rural livelihood in a bimodal agricultural system in irrigated drylands. Land Use Policy 35, 95-106.

Djumaeva, D., Djanibekov, N., Vlek, P.L.G., Martius, C. and Lamers, J.P.A, 2009. Options for optimizing dairy feed rations with foliage of trees grown in the irrigated drylands of Central Asia. Research Journal of Agriculture and Biological Sciences 5(5), 698-708.

Erenstein, O., Thorpe, W., 2010. Crop-livestock interactions along agro-ecological gradients: A meso-level analysis in the Indo-Gangetic Plains, India. Environment, Development and Sustainability 12, 669-689.

FAO (Food and Agriculture Organization), 2010. FAOstat production database: Live animals. http://faostat.fao.org. Accessed 07 February 2011.

Fritzsch, J., Wegener, S., Buchenrieder, G., Curtiss, J., Gomez y Paloma, S., 2011. Is there a future for semi-subsistence farm households in Central and southeastern Europe? A multiobjective linear programming approach. Journal of Policy Modelling 33, 70-91.

Iñiguez, L., Suleimenov, M., Yusupov, S., Ajibekov, A., Kineev, M., Kheremov, S., Abdusattarov, A., Thomas, D., 2004. Livestock production in Central Asia: Constraints and research opportunities, in: Ryan, J., Vlek, P.L.G., Paroda, R. 
(Eds) Agriculture in Central Asia: Research for Development. ICARDA, Aleppo, Syria, pp. 278-301.

Iñiguez, L., Suleimenov, M., Yusupov, S., Ajibekov, A., Kineev, M., Kheremov, S., Abdusattarov, A., Thomas, D., Musaeva, M., 2005. Livestock production in Central Asia: Constraints and opportunities. ICARDA Caravan 22, 18-22.

Khorezm Regional Administration, 2009. Talk of the Major of Khorezm region - O. Ollaberganov in the meeting about results of socio-economic development of the region in 2008 and important major duties for further economic development in 2009. http://xorazm.uz/maruzalar/?phpMyAdmin=jvTIqg6F00yOdWttliaauOEdld. Accessed 27 March 2011.

Kienzler, K., Lamers, J.P.A., McDonald, A., Mirzabaev, A., Ibragimov, N., Egamberdiev, O, Ruzibaev, E, Akramkhanov, A., 2012. Conservation agriculture in Central Asia - What do we know and where do we go from here? Field Crops Research 132, 95-105.

Lee, S.D., Kennard, R.O., Kayouli, C., 1998. Manual of Smallholder Milk Production in the South Pacific. FAO, Rome.

Lerman, Z., 2008a. Agricultural development in Uzbekistan: The effect of ongoing reforms. Discussion Paper No. 7.08. Department of Agricultural Economics and Management, Hebrew University of Jerusalem, Rehovot, Israel.

Lerman, Z., 2008b. Agricultural development in Central Asia: A survey of Uzbekistan, 2007-2008. Eurasian Geography and Economics 49(4), 481-505.

Makhmudovich, M., 2001. Country pasture/forage resource profile: Uzbekistan. FAO, Rome.

Müller, M.J., 1996. Handbuch ausgewählter Klimastationen der Erde. Universität Trier, Trier.

Müller, M. 2006. A general equilibrium approach to modeling water and land use reforms in Uzbekistan. PhD thesis. Center for Development Research (ZEF), Rheinische Friedrich-Wilhelms-Universität, Bonn.

Nordblom, T.L., Goodchild, A.V., Shomo, F., Gintzburger, G., 1997. Dynamics of feed resources in mixed farming systems of west/central Asia - North Africa, in: Renard, C. (Ed) Crop Residues in Sustainable Mixed Crop/Livestock Farming Systems. CABI, Wallingford, pp. 131-148. 
NRC (National Research Council), 1981. Nutrient requirements of goats: Angora, dairy and meat goats in temperate and tropical countries. National Academy Press, Washington-DC.

NRC (National Research Council), 2001. Nutrient requirements of dairy cattle. Seventh revised edition. National Academy Press, Washington-DC.

President of the Republic of Uzbekistan, 2006. Measures for Stimulation of Livestock Expansion in Household Plots, Dehkan and Private Farms. Presidential Resolution No. 308, 23 March 2006. Republic of Uzbekistan, Tashkent. President of the Republic of Uzbekistan, 2008. Additional Measures for Strengthening Livestock Expansion in Household Plots, Dehkan and Private Farms and Increasing Livestock Production. Presidential Resolution No. 842, 21 April 2008. Republic of Uzbekistan, Tashkent.

Preston, R.L., 1966. Protein requirements of growing-finishing cattle and lambs. The Journal of Nutrition 90, 157-160.

Rudenko, I., Grote, U., Lamers, J.P.A., Martius, C., 2008. Wert schöpfen, Wasser sparen. Effizienzsteigerung im usbekischen Baumwollsektor, in: Sapper, M., Weichsel, V. (Eds) Grünbuch Politische Ökologie im Osten Europas. Osteuropa 58, 407-418. (Berliner Wissenschafts-Verlag, Berlin, Germany).

Rudenko, I., Nurmetov, K., Lamers, J.P.A., 2012. State order and policy strategies in the cotton and wheat value chains, in: Martius, C., Rudenko, I., Lamers, J.P.A., Vlek, P.L.G. (Eds) Cotton, water, salts and soums - economic and ecological restructuring in Khorezm, Uzbekistan. Springer: Dordrecht, Heidelberg, London, New York, pp. 371-387.

Schiere, J.B., 2010. Cereal straws as ruminant feeds: Problems and prospects revisited. Animal Nutrition and Feed Technology 10S, 127-153.

Schiere, J.B., Joshi, A.L., Seetharam, A., Oosting, S.J., Goodchild, A.V., Deinum, B., van Keulen, H., 2004. Grain and straw for whole plant value: Implications for crop management and genetic improvement strategies. Experimental Agriculture 40, 277-294.

State Statistics Committee of the Republic of Uzbekistan, 2010. Demographic information. http://www.stat.uz/demographic. Accessed 13 April 2011. 
State Statistics Committee of the Republic of Uzbekistan, 2011. Statistical review of Uzbekistan. http://www.stat.uz/en/reports/165. Accessed 12 April 2011.

Suleimenov, M., Oram, P., 2000. Trends in feed, livestock production, and rangelands during the transition period in three Central Asian countries. Food Policy 25, 681-700.

Tischbein, B., Awan, U.K., Abdullaev, I., Bobojonov, I., Conrad, C., Forkutsa, I., Ibrakhimov, M., Poluasheva, G., 2012. Water management in Khorezm: Current situation and options for improvement (hydrological perspective), in: Martius, C., Rudenko, I., Lamers, J.P.A., Vlek, P.L.G. (Eds) Cotton, Water, Salts and Soums - Economic and Ecological Restructuring in Khorezm, Uzbekistan. Springer, Dordrecht, Heidelberg, London, New York, pp. 69-92.

Tomme, M.F., Novikov, E.A., 1963. General Zootechnology. Sel'skochoz, Moscow.

USDA, 2011. Uzbekistan livestock report 2011. Gain Report UZ1101, USDA Tashkent, Uzbekistan. On line at http://gain.fas.usda.gov/Recent\%20GAIN\%20Publications/Uzbekistan\%20Lives tock\%20Report\%202011_Tashkent_Uzbekistan\%20-\%20Republic\%20of_4-262011.pdf

Vavilov, N.I., 1997. Five continents. International Plant Genetic Resources Institute, Rome.

Yusupov, Y.B., Lerman, Z., Chertovitskiy, A.S., Akbarov, O.M., 2010. Livestock production in Uzbekistan: Current state, issues, prospects. Review in the context of agricultural sector development trends. UN Development Programme, Tashkent.

Zemmelink, G., Brouwer, B.O., Subagiyo, I., 1992. Feed utilization and the role of ruminants in farming systems, in: Ibrahim, M.N.M., Jong, R. de, Bruchem, J. van, Purnomo (Eds) Livestock and feed development in the tropics. Proceedings of the International Seminar held at Brawijawa University, Malang, Indonesia, 21-25 October 1991. Agricultural University, Wageningen, The Netherlands, Brawijaya University, Malang Indonesia, Commission of European Communities, Brussels, pp. 444-456. 


\section{Table 1}

Farm resources and their relative intensities by livestock farming system.

\begin{tabular}{|c|c|c|c|c|c|c|c|}
\hline \multirow[t]{2}{*}{ Item } & \multirow[t]{2}{*}{ Unit } & \multicolumn{3}{|c|}{ LS farms } & \multicolumn{3}{|c|}{$\mathrm{HH}$ farms } \\
\hline & & $\mathrm{n}$ & Mean & SD & $\mathrm{n}$ & Mean & $\mathrm{SD}$ \\
\hline \multicolumn{8}{|l|}{ Land } \\
\hline Cultivated area & ha & 56 & \multicolumn{2}{|c|}{$22.16 \quad 17.96$} & 80 & 0.20 & 0.16 \\
\hline Rangeland $^{\&}$ & ha & 3 & \multicolumn{2}{|c|}{$1.5-10.5^{\mathrm{R}}$} & 0 & - & - \\
\hline \multicolumn{8}{|l|}{ Labour and human capital } \\
\hline Family labour (total) & Adult equivalent\# & 56 & 7.0 & 2.9 & 80 & 5.1 & 1.8 \\
\hline Family labour (on-farm $)^{\mathrm{F}}$ & $\mathrm{AE}$ & 56 & 5.1 & 3.6 & 75 & 3.0 & 1.1 \\
\hline Permanent farm labour* & $\mathrm{AE}$ & 56 & 6.8 & 5.2 & 75 & 3.0 & 1.0 \\
\hline Farmer's age & Years & 56 & 50 & 12 & 80 & 49 & 14 \\
\hline Farmer's farming experience & Years & 55 & 23 & 14 & 80 & 26 & 17 \\
\hline Farmer worked in Shirkat & $\%$ & 56 & 66 & - & 80 & 79 & - \\
\hline Education of farmer & $\%$ college or MSc & 56 & 79 & - & 80 & 53 & - \\
\hline \multicolumn{8}{|l|}{ Fixed capital, assets } \\
\hline Livestock units, all species & LU & 56 & 32.5 & 21.7 & 80 & 2.9 & 2.2 \\
\hline Cattle livestock units & LU & 55 & 26.7 & 18.1 & 79 & 2.2 & 1.4 \\
\hline Winter housing & $\mathrm{m}^{2}$ cattle-LU ${ }^{-1}$ & 55 & 201 & $-106^{\mathrm{R}}$ & 79 & 20 & $4-80^{R}$ \\
\hline Farm possesses animal cart ${ }^{\mathrm{A}}$ & $\%$ & 56 & 39 & - & 80 & 43 & - \\
\hline Farm possesses tractor & $\%$ & 56 & 75 & - & 80 & 14 & - \\
\hline Farm possesses pump & $\%$ & 56 & 73 & - & 80 & 6 & - \\
\hline \multicolumn{8}{|l|}{ Intensities } \\
\hline $\begin{array}{l}\text { Permanent farm labour force } \\
\text { per livestock unit }\end{array}$ & $\mathrm{AE} \mathrm{LU} \mathrm{L}^{-1}$ & 56 & 0.28 & 0.35 & 76 & 1.52 & 0.94 \\
\hline $\begin{array}{l}\text { Permanent farm labour force } \\
\text { per cattle livestock unit }\end{array}$ & $\mathrm{AE} \mathrm{LU} \mathrm{L}^{-1}$ & 55 & 0.35 & 0.40 & 74 & 2.03 & 1.42 \\
\hline $\begin{array}{l}\text { Permanent farm labour force } \\
\text { per cultivated area }\end{array}$ & $\mathrm{AE} h \mathrm{ha}^{-1}$ & 56 & 0.36 & 0.20 & 76 & 18.72 & 9.04 \\
\hline $\begin{array}{l}\text { Cultivated area per livestock } \\
\text { unit }\end{array}$ & ha $\mathrm{LU}^{-1}$ & 56 & 0.79 & 0.68 & 80 & 0.09 & 0.07 \\
\hline $\begin{array}{l}\text { Cultivated land area per } \\
\text { cattle head }\end{array}$ & ha head ${ }^{-1}$ & 55 & 0.56 & 0.41 & 79 & 0.06 & 0.04 \\
\hline
\end{tabular}

\& Grazing on rangelands was rare; instead cattle grazed more frequently on communal land near canals, lakes, riversides, forest margins or on stubbles. The only LS farm without cattle, kept sheep instead and disposed over 160 ha of rangeland. ${ }^{R}$ The range is given instead of standard error. \#Adult equivalent was subsequently abbreviated as AE. ${ }^{\mathrm{F}}$ Family labour on $\mathrm{HH}$ farms is not necessarily referring to full-time adult equivalents as full and part-time family workers were not distinguished. *In LS farms permanent labour force comprised family and wage labour. There were also day wage labourers in the LS farms; their contribution to total labour force could not be assessed in this study. ${ }^{\mathrm{A}}$ Animal cart was mainly horse cart in LS farms, and donkey cart in $\mathrm{HH}$ farms. 


\section{Table 2}

Farm animal stocks by livestock farming system.

\begin{tabular}{|c|c|c|c|c|c|c|c|c|c|c|}
\hline \multirow{2}{*}{$\begin{array}{l}\text { Animal category } \\
\text { (head) }\end{array}$} & \multicolumn{5}{|c|}{ LS farms $(\mathrm{n}=55)$} & \multicolumn{5}{|c|}{ HH farms $(n=79)$} \\
\hline & \multicolumn{2}{|c|}{ Median } & \multirow{2}{*}{$\begin{array}{r}\text { Mean } \\
44.9\end{array}$} & \multirow{2}{*}{$\frac{\text { SD }}{7.2}$} & \multirow{2}{*}{$\frac{\mathrm{CV}}{62}$} & \multicolumn{2}{|c|}{ Median } & \multirow{2}{*}{$\begin{array}{r}\text { Mean } \\
3.9\end{array}$} & \multirow{2}{*}{$\frac{\text { SD }}{2.5}$} & \multirow{2}{*}{$\frac{\mathrm{CV}}{63}$} \\
\hline Cattle (total) & & 42 & & & & & 3 & & & \\
\hline Cows & & 14 & 14.6 & 9.3 & 64 & & 1 & 1.4 & 0.9 & 65 \\
\hline Calves & & 7 & 8.2 & 6.1 & 74 & & 1 & 1.0 & 0.9 & 82 \\
\hline Yearlings & & 6 & 7.1 & 6.4 & 90 & & 0 & 0.6 & 0.7 & 131 \\
\hline Mating bulls & & 0 & 0.7 & 1.3 & 168 & & 0 & 0 & 0 & 0 \\
\hline Non-fattening bulls & & 5 & 7.2 & 9.4 & 129 & & 0 & 0.3 & 0.6 & 175 \\
\hline Fattening bulls & & 4 & 7.0 & 11.4 & 163 & & 0 & 0.6 & 0.9 & 150 \\
\hline & $\mathrm{n}$ & & & & & $\mathrm{n}$ & & & & \\
\hline Chicken & 27 & 94 & 137.1 & 126.7 & 92 & 66 & 9 & 19.8 & 61.1 & 308 \\
\hline Ducks, turkey & - & - & - & - & - & 25 & 4 & 6.7 & 10.2 & 152 \\
\hline Sheep & 28 & 12 & 25.9 & 34.3 & 133 & 24 & 2 & 3.6 & 5.2 & 146 \\
\hline Goat & 4 & 7 & 11.8 & 12.6 & 107 & - & - & - & - & - \\
\hline Donkeys & - & - & - & - & - & 18 & 1 & 1.2 & 0.7 & 60 \\
\hline Horses & 17 & 1 & 1.4 & 1.0 & 74 & 6 & 1 & 1.0 & 0.0 & 0 \\
\hline
\end{tabular}




\section{Table 3}

Crop area, fertilizer use, annual revenue from cropping and productivity by livestock farming system.

\begin{tabular}{|c|c|c|c|c|c|c|c|}
\hline \multirow[t]{2}{*}{ Item } & \multirow[t]{2}{*}{ Unit } & \multicolumn{3}{|c|}{ LS farms } & \multicolumn{3}{|c|}{$\mathrm{HH}$ farms } \\
\hline & & $\mathrm{n}$ & Mean & SD & $\mathrm{n}$ & Mean & SD \\
\hline Allocated area & ha & 56 & 21.42 & 17.20 & 80 & 0.32 & 0.22 \\
\hline Total fertilizer costs & USD year $^{-1}$ & 55 & 2,778 & 2,205 & 77 & 69 & 42 \\
\hline Total harvest value* & USD year $^{-1}$ & 56 & 33,901 & 25,543 & 78 & 907 & 600 \\
\hline Fertilizer per ha allocated & USD hä ${ }^{-1}$ & 55 & 145 & 88 & 77 & 227 & 105 \\
\hline Harvest value per ha allocated & USD ha-1 & 55 & 1,676 & 589 & 77 & 2,879 & 1,277 \\
\hline $\begin{array}{l}\text { Harvest value minus fertilizer } \\
\text { per ha allocated }\end{array}$ & USD ha $^{-1}$ & 55 & 1,531 & 561 & 77 & 2,652 & 1,247 \\
\hline $\begin{array}{l}\text { Percentage of feed value of } \\
\text { total value of crops }\end{array}$ & $\%$ & 56 & 48 & 3 & 78 & 32 & 2 \\
\hline
\end{tabular}




\section{Table 4}

Most important feeds by category used by farms in two livestock systems, sorted according to perceived importance by LS farmers.

\begin{tabular}{|c|c|c|c|c|c|c|c|c|c|c|}
\hline \multirow[t]{2}{*}{ Feed category } & \multicolumn{2}{|c|}{ First } & \multicolumn{2}{|c|}{ Second } & \multicolumn{2}{|c|}{ Third } & \multicolumn{2}{|c|}{ Fourth } & \multicolumn{2}{|c|}{ Fifth } \\
\hline & LS & $\mathrm{HH}$ & LS & $\mathrm{HH}$ & LS & $\mathrm{HH}$ & LS & $\mathrm{HH}$ & LS & $\mathrm{HH}$ \\
\hline Crop by-products & \multicolumn{2}{|c|}{$\begin{array}{l}\text { Cottonseed } \\
\text { cake } 2\end{array}$} & \multicolumn{2}{|c|}{ Cotton husk } & \multicolumn{2}{|c|}{ Wheat bran } & \multicolumn{2}{|c|}{$\begin{array}{l}\text { Rice hull }+ \\
\text { bran }\end{array}$} & \multicolumn{2}{|c|}{$\begin{array}{c}\text { Cottonseed } \\
\text { cake } 1\end{array}$} \\
\hline Index & 5.1 & 5.0 & 4.2 & 2.2 & 3.4 & 3.4 & 1.4 & 2.0 & 0.8 & 0.9 \\
\hline$\%$ of farms & 89 & 88 & 85 & 44 & 80 & 75 & 47 & 54 & 15 & 21 \\
\hline Straws and hays & \multicolumn{2}{|c|}{ Wheat } & \multicolumn{2}{|c|}{ Rice } & \multicolumn{2}{|c|}{ Cane } & \multicolumn{2}{|c|}{ Licorice } & \multicolumn{2}{|c|}{ "Weeds" } \\
\hline Index & 4.9 & 5.6 & 3.4 & 3.2 & 2.5 & 2.5 & 2.4 & 1.0 & 1.7 & 2.2 \\
\hline$\%$ of farms & 82 & 95 & 67 & 63 & 58 & 60 & 67 & 34 & 67 & 63 \\
\hline Forages & \multicolumn{2}{|c|}{ Maize } & \multicolumn{2}{|c|}{ Sorghum } & \multicolumn{2}{|c|}{ Alfalfa } & \multicolumn{2}{|c|}{ Silage } & \multicolumn{2}{|c|}{ Black sorgh. } \\
\hline Index & 2.6 & 0.7 & 2.3 & 2.4 & 1.9 & 0.3 & 1.0 & - & 0.1 & 0.0 \\
\hline$\%$ of farms & 75 & 28 & 80 & 85 & 67 & 14 & 31 & - & 2 & 3 \\
\hline Grains (broken) & \multicolumn{2}{|c|}{ Rice } & \multicolumn{2}{|c|}{ Maize } & \multicolumn{2}{|c|}{ Sorghum } & \multicolumn{2}{|c|}{ Wheat } & & \\
\hline Index & 1.3 & 0.7 & 1.3 & 0.1 & 0.4 & - & 0.1 & - & & \\
\hline$\%$ of farms & 58 & 35 & 44 & 8 & 20 & - & 4 & - & & \\
\hline Vegetables & \multicolumn{2}{|c|}{ Carrot } & \multicolumn{2}{|c|}{ Beet } & \multicolumn{2}{|c|}{ Pumpkin } & \multicolumn{2}{|c|}{ Turnip } & \multicolumn{2}{|c|}{ Radish } \\
\hline Index & 1.6 & 0.6 & 1.6 & 0.6 & 1.0 & 0.5 & 0.3 & - & 0.0 & - \\
\hline$\%$ of farms & 45 & 40 & 41 & 30 & 36 & 30 & 11 & - & 5 & - \\
\hline
\end{tabular}

$\mathrm{LS}=55$ farms ( $\mathrm{n}=22$ in vegetables), $\mathrm{HH}=80$ farms ( $\mathrm{n}=10$ in vegetables). The indices are only to be compared within row and system as the maximum levels differed (In LS: crop by-products and straws and hays 6 , forages and vegetables 4 , and grains 3 levels of importance. In HH: crop by-products and straws and hays 6 , forages 3 , grains and vegetables 2 levels of importance). The percentages relate to farmers who used this feed. 


\section{Table 5}

Farm-produced supply versus demand of metabolizable energy and crude protein by livestock farming system.

\begin{tabular}{|c|c|c|c|c|c|c|c|}
\hline \multirow[t]{2}{*}{ Item } & \multirow[t]{2}{*}{ Unit } & \multicolumn{3}{|c|}{$\mathrm{LS}$ farms $(\mathrm{n}=55)$} & \multicolumn{3}{|c|}{ HH farms $(n=77)$} \\
\hline & & Mean & Min & $\operatorname{Max}$ & Mean & Min & $\operatorname{Max}$ \\
\hline Supply & $\begin{array}{l}\text { ME MJ year-1 } \\
\text { CP kg year }{ }^{-1}\end{array}$ & $\begin{array}{r}1,161,269 \\
14,890\end{array}$ & $\begin{array}{r}46,440 \\
896\end{array}$ & $\begin{array}{r}4,928,121 \\
69,766\end{array}$ & $\begin{array}{r}20,460 \\
211\end{array}$ & $\begin{array}{r}561 \\
10\end{array}$ & $\begin{array}{r}71,484 \\
1,312\end{array}$ \\
\hline Demand & $\begin{array}{l}\text { ME MJ year }{ }^{-1} \\
\text { CP kg year-1 }\end{array}$ & $\begin{array}{r}749,750 \\
9,301\end{array}$ & $\begin{array}{r}54,699 \\
721\end{array}$ & $\begin{array}{r}2,767,306 \\
34,010\end{array}$ & $\begin{array}{r}63,900 \\
798\end{array}$ & $\begin{array}{r}9,129 \\
105\end{array}$ & $\begin{array}{r}334,212 \\
4,139\end{array}$ \\
\hline $\begin{array}{l}\text { Portion } \\
\text { covered }\end{array}$ & $\begin{array}{l}\text { ME MJ year-1 } \\
\text { CP kg year }{ }^{-1}\end{array}$ & $\begin{array}{l}155 \% \\
160 \%\end{array}$ & $\begin{array}{l}10 \% \\
17 \%\end{array}$ & $\begin{array}{l}499 \% \\
579 \%\end{array}$ & $\begin{array}{l}32 \% \\
26 \%\end{array}$ & $\begin{array}{l}4 \% \\
4 \%\end{array}$ & $\begin{array}{l}225 \% \\
178 \%\end{array}$ \\
\hline
\end{tabular}




\section{Table 6}

Relative contributions of feed and cash produce from the main crops grown, as recalled by LS farmers.

\begin{tabular}{|c|c|c|c|c|c|c|c|c|c|c|c|c|c|}
\hline & \multirow[t]{2}{*}{ Unit } & \multicolumn{3}{|c|}{ Cotton } & \multicolumn{3}{|c|}{ Wheat } & \multicolumn{3}{|c|}{ Maize } & \multicolumn{3}{|c|}{ Rice } \\
\hline & & $\mathrm{n}$ & Mean & SD & $\mathrm{n}$ & Mean & $\mathrm{SD}$ & $\mathrm{n}$ & Mean & $\mathrm{SD}$ & $\mathrm{n}$ & Mean & $\mathrm{SD}$ \\
\hline LS sample farms had this crop & $\%$ & 56 & $70 \%$ & & 56 & $57 \%$ & & 56 & $52 \%$ & & 56 & $45 \%$ & \\
\hline Average area allocated & ha & 39 & 10.3 & 7.4 & 32 & 6.3 & 7.3 & 29 & 3.0 & 2.8 & 25 & 3.3 & 2.1 \\
\hline Grain or fiber yield & $\mathrm{Mg} \mathrm{ha}^{-1}$ & 32 & 2.9 & 0.6 & 28 & 4.2 & 1.4 & 26 & 4.0 & 1.8 & 21 & 4.5 & 1.5 \\
\hline Stover or straw yield ${ }^{\mathrm{St}}$ & $\mathrm{Mg} \mathrm{ha}^{-1}$ & & 5.0 & & 23 & 3.8 & 3.1 & 22 & 19.3 & 12.0 & 23 & 9.0 & 5.8 \\
\hline Stover, straw: fiber, grain yield & ratio & & 1.75 & & 22 & 0.47 & 0.62 & 22 & 5.05 & 3.44 & 21 & 2.14 & 1.45 \\
\hline Price of fiber, grain (state)* & $\mathrm{USD} \mathrm{kg}^{-1}$ & & 0.26 & & & 0.10 & & & & & & & \\
\hline Price of grain (market) $)^{\#}$ & $\mathrm{USD} \mathrm{kg}^{-1}$ & & & & 5 & 0.55 & 0.01 & 5 & 0.45 & 0.03 & 5 & 0.87 & 0.06 \\
\hline Price of crushed rice $\$$ & $\mathrm{USD} \mathrm{kg}^{-1}$ & & & & & & & & & & 5 & 0.52 & 0.04 \\
\hline Price of rice hull and bran & $\mathrm{USD} \mathrm{kg}^{-1}$ & & & & & & & & & & 5 & 0.15 & 0.04 \\
\hline Price of stover or straw ${ }^{\#}$ & $\mathrm{USD} \mathrm{kg}^{-1}$ & 5 & 0.05 & 0.01 & & 0.04 & 0.01 & & 0.04 & 0.02 & 5 & 0.04 & 0.01 \\
\hline Crushed rice grain value $e^{\S}$ & USD ha $^{-1}$ & & & & & & & & & & 21 & 119 & 43 \\
\hline Rice hull and bran value ${ }^{\S}$ & $\mathrm{USD} \mathrm{ha}^{-1}$ & & & & & & & & & & 21 & 197 & 84 \\
\hline Total value of fiber or grain & $\mathrm{USD} \mathrm{ha}^{-1}$ & 32 & 739 & 159 & & 1,280 & 759 & & 1,727 & 743 & 21 & 2,890 & 1,039 \\
\hline Total value of stover or straw & $\mathrm{USD} \mathrm{ha}^{-1}$ & 39 & 240 & 43 & & 166 & 140 & & 828 & 620 & 23 & 400 & 287 \\
\hline Contribution of feed to total crop value ${ }^{\wedge}$ & $\%$ & 32 & $25 \%$ & $5 \%$ & 23 & $17 \%$ & $16 \%$ & & $30 \%$ & $17 \%$ & 21 & $22 \%$ & $7 \%$ \\
\hline Mineral fertilizer rate ${ }^{\circ}$ & $\mathrm{kg} \mathrm{ha}^{-1}$ & 23 & 854 & 197 & 30 & 671 & 264 & 28 & 532 & 215 & 23 & 891 & 514 \\
\hline Mineral fertilizer cost & $\mathrm{USD}_{\mathrm{ha}}^{-1}$ & 23 & 225 & 64 & & 178 & 80 & & 131 & 57 & 23 & 216 & 112 \\
\hline
\end{tabular}

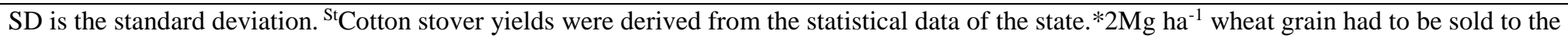
state. \#The average was calculated from five district averages of the first half of $2008 .{ }^{\$}$ Crushed rice price was $3 / 5$ of polished grain price. ${ }^{\S}$ From $100 \%$ rice gain yield, $65 \%$ were estimated as polished grain, $5 \%$ as crushed grain and $30 \%$ as hull and bran. ${ }^{\circ}$ The mineral fertilizer as product bought in the shop is meant, thus not its active fertilizing content. ${ }^{\wedge}$ Cotton stover is almost no longer used as feed, though this was a practice in former times in the study region.

Feed from rice crop includes crushed grain, hull and bran, and straw. 
Table 7

Composition of annual revenue from cattle farming by livestock farming system.

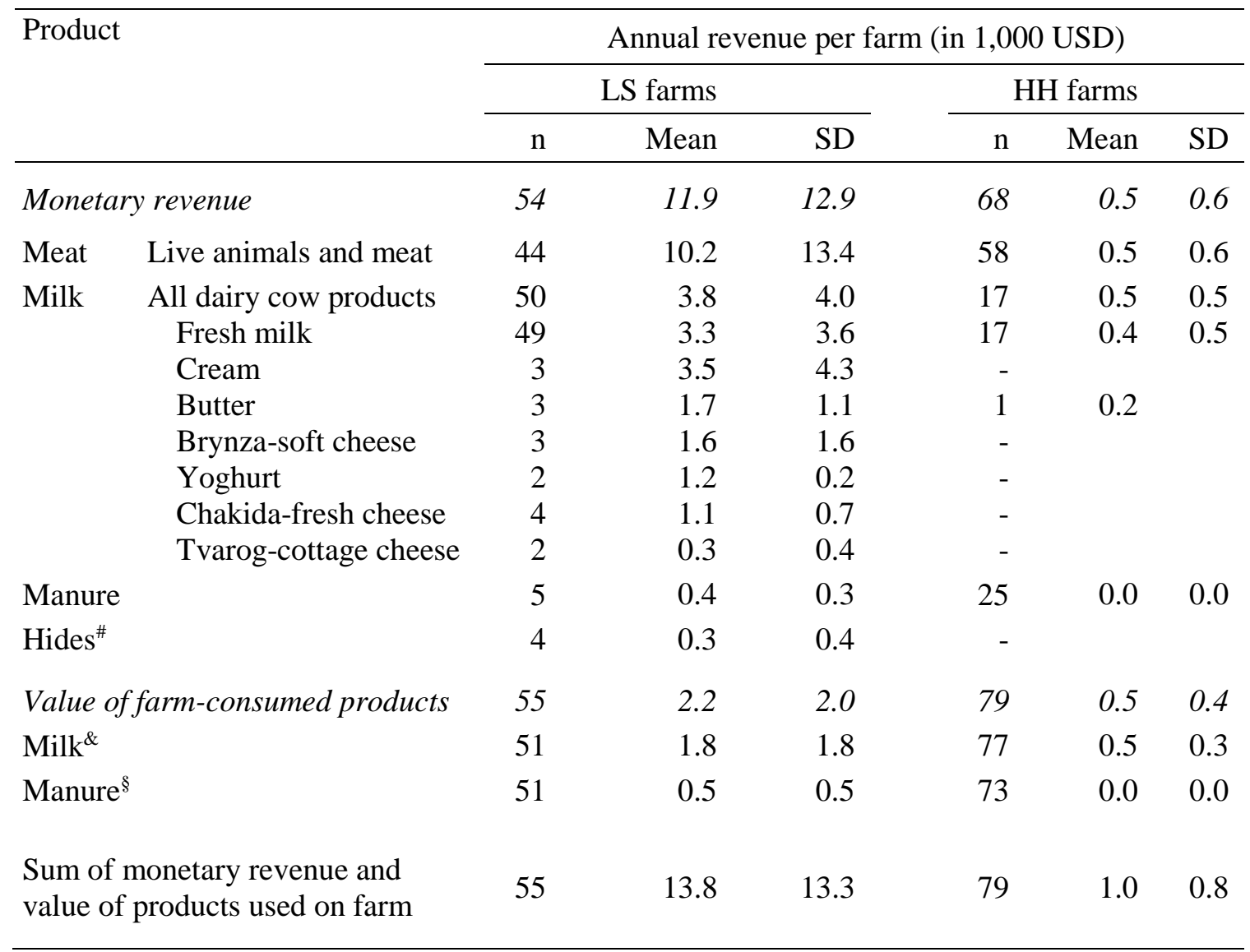

\footnotetext{
During the survey period (18 Jan to 02 Jun 2008) the average currency conversion rate was: 1 USD = 1300 UZS (Uzbekistan som; www.oanda.com); \#in Khazarasp only; \&In few cases of LS farms no price was available, then the mode was taken (0.23 USD L-1); §Manure was valued by an average of $3.63 \mathrm{USD} \mathrm{Mg}^{-1}$; Meat prices (Jan to May 2008 averages) differed by district and ranged from $3.45 \mathrm{USD} \mathrm{kg}^{-1}$ in Kushkupir to $3.73 \mathrm{USD} \mathrm{kg}^{-1}$ in Khazarasp.
} 
Table 8

Cattle productivity by livestock farming system.

\begin{tabular}{|c|c|c|c|c|c|c|}
\hline \multirow[t]{2}{*}{ Productivity measure } & \multicolumn{3}{|c|}{ LS farms } & \multicolumn{3}{|c|}{$\mathrm{HH}$ farms } \\
\hline & $\mathrm{n}$ & Mean & $\mathrm{SD}$ & $\mathrm{n}$ & Mean & SD \\
\hline $\begin{array}{l}\text { Daily liters milked per milking cow } \\
\left(\mathrm{L} \mathrm{cow} \text { cay }^{-1}\right)\end{array}$ & 52 & $6.0^{\mathrm{a}}$ & 2.9 & 74 & $4.1^{\mathrm{b}}$ & 2.6 \\
\hline $\begin{array}{l}\text { Dairy products sold per milking cow } \\
\left.\text { (USD cow } \text { year }^{-1}\right)\end{array}$ & 49 & $480^{\mathrm{a}}$ & 427 & 16 & $352^{\mathrm{a}}$ & 528 \\
\hline 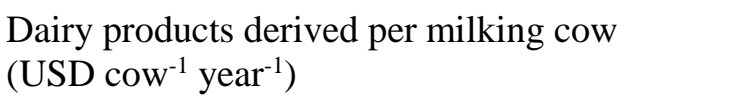 & 52 & $712^{\mathrm{a}}$ & 508 & 74 & $465^{\mathrm{b}}$ & 360 \\
\hline $\begin{array}{l}\text { Total products sold per cattle livestock unit } \\
\text { kept }\left(\mathrm{USD} \mathrm{LU}^{-1} \text { year }^{-1}\right)\end{array}$ & 54 & $487^{\mathrm{a}}$ & 420 & 68 & $281^{\mathrm{b}}$ & 395 \\
\hline $\begin{array}{l}\text { Total products derived per cattle livestock unit } \\
\text { kept (USD LU } \text { year }^{-1} \text { ) }\end{array}$ & 55 & $580^{\mathrm{a}}$ & 466 & 79 & $538^{a}$ & 450 \\
\hline
\end{tabular}

Products derived include products sold and products consumed on farm valued at market prices. During the survey period (18 Jan to 02 Jun 2008) the average conversion rate was: 1 USD $=1300$ UZS (Uzbekistan som;

www.oanda.com). Values followed by the same superscript within one row are not significantly different at $\mathrm{P}<0.05$ according to the t-test. 


\section{Annex}

\section{Table a}

Criteria used for estimating energy and protein requirements of the different cattle categories kept in the farms.

\begin{tabular}{|c|c|c|c|c|c|c|}
\hline $\begin{array}{l}\text { Production characteristics and related } \\
\text { requirements }\end{array}$ & Calf & Yearling & $\begin{array}{r}\text { Cow } \\
(\mathrm{HH})\end{array}$ & $\begin{array}{l}\text { Cow } \\
(\mathrm{LS})\end{array}$ & $\begin{array}{r}\text { Bull, not } \\
\text { fattened } \\
\end{array}$ & $\begin{array}{r}\text { Bull, } \\
\text { fattened }\end{array}$ \\
\hline Liveweight $(\mathrm{kg})$ & 70 & 140 & 300 & 300 & 350 & 350 \\
\hline Metabolic liveweight $\left(\mathrm{LW}^{0.75}, \mathrm{~kg}\right)$ & 24.2 & 40.7 & 72.1 & 72.1 & 80.9 & 80.9 \\
\hline Daily milk yield $\left(\mathrm{kg} \mathrm{day}^{-1}\right)$ & & & 4.2 & 6.2 & & \\
\hline Daily weight gain (DWG, $\mathrm{kg} \mathrm{day}^{-1}$ ) & 0.332 & 0.219 & 0.070 & 0.070 & - & 0.400 \\
\hline $\begin{array}{l}\text { Energy requirement for maintenance } \\
\left(\mathrm{MJ} \mathrm{day}^{-1}\right)\end{array}$ & 12.39 & 20.84 & 36.91 & 36.91 & 41.43 & 41.43 \\
\hline Adjustments for production & $\begin{array}{l}+20 \% \text { for } \\
\text { growth }\end{array}$ & $\begin{array}{r}+20 \% \\
\text { for } \\
\text { growth }\end{array}$ & $\begin{array}{r}+15 \mathrm{MJ} \text { per } \mathrm{d} \\
\text { month of } \\
+5.3 \mathrm{MJ} \text { per } \\
\text { months }\end{array}$ & $\begin{array}{l}\text { the last } \\
\text { ancy } \\
\text { lk for } 8 \\
\text { ion }\end{array}$ & & $\begin{array}{r}+15.24 \mathrm{MJ} \\
\text { per day for } \\
\text { DWG }\end{array}$ \\
\hline
\end{tabular}

\begin{tabular}{lrrrrrr} 
Total metabolizable energy (MJ day & -1 \\
) & 14.87 & 25.01 & 53.15 & 60.53 & 41.43 & 56.67 \\
\hline
\end{tabular}

$\begin{array}{lllllll}\text { Crude Protein for maintenance and } & 185 & 287 & 450 & 450 & 474 & 649\end{array}$

DWG $\left(\mathrm{g} \mathrm{day}^{-1}\right)$

Adjustments for gestation and milk $\quad+24 \mathrm{~g} \mathrm{CP}$ in last month of pregnancy

production

$+85 \mathrm{~g} \mathrm{CP}$ per kg milk for 8 months

\begin{tabular}{lllllll} 
Total crude protein $\left(\right.$ g day $\left.^{-1}\right)$ & 185 & 287 & 690 & 803 & 474 & 649 \\
\hline
\end{tabular}

HH: household farms, LS: medium-scale crop-livestock farms

Sources: Body live weights are own estimates; maintenance (0.512 MJ ME $\left.\mathrm{kg} \mathrm{LW}^{-0.75}\right)$ and DWG energy requirements according to Zemmelink et al. (1992); crude protein requirement $\left(5.86 \mathrm{~g} \mathrm{CP} \mathrm{x} \mathrm{LW}{ }^{0.75} \mathrm{x}\right.$ (1+0.924 g CP x DWG)) from Preston (1966); pregnancy and milk requirements from Lee et al. (1998). 


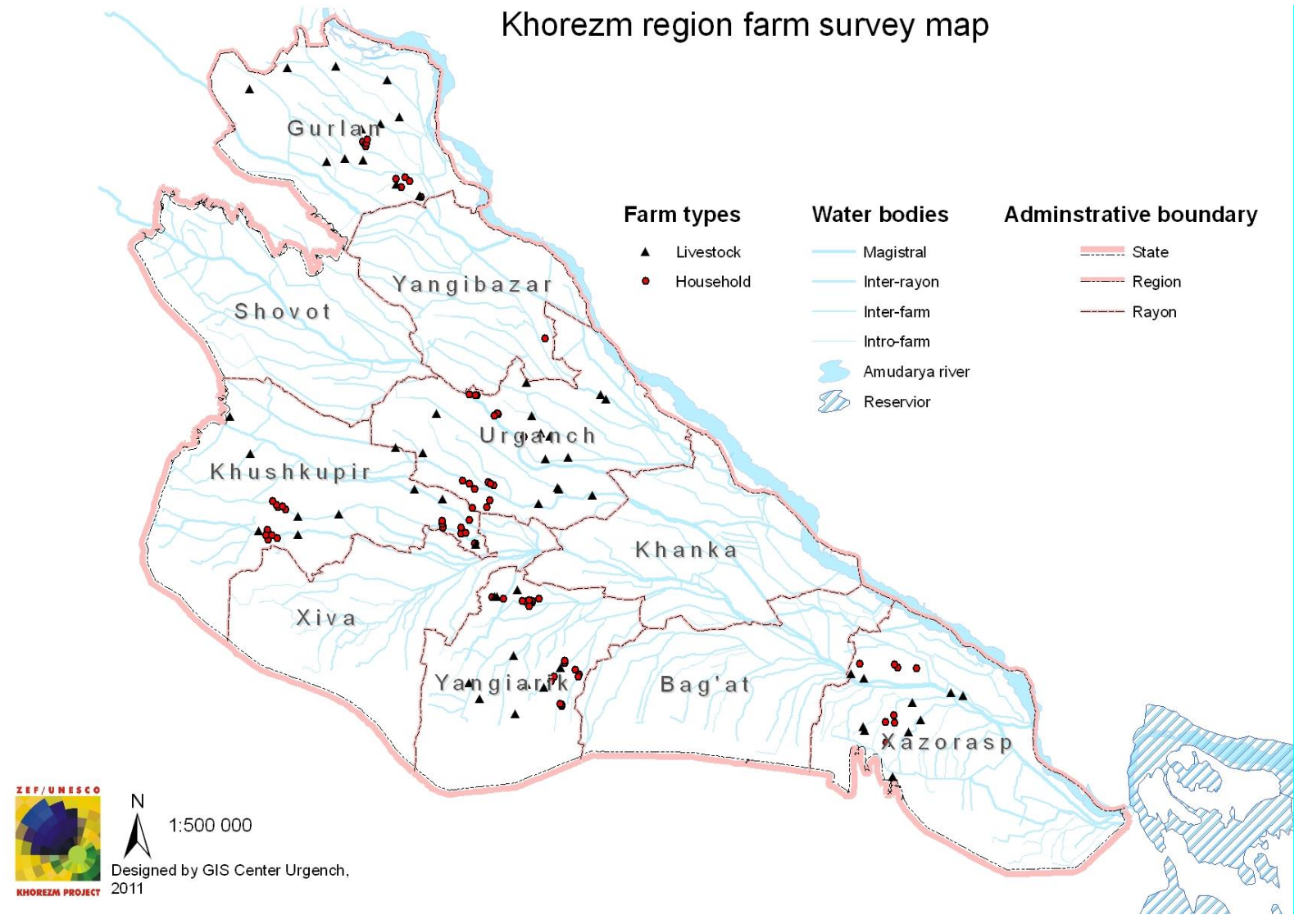

Fig. 1. Map of the study region with the location of the respondents of both farm types.

(Livestock=LS farms, Household=HH farms) 